\title{
Science to Support the Understanding of Ohio's Water Resources
}

\section{Introduction}

Ohio's water resources support a complex web of human activities and nature - clean and abundant water is needed for drinking, recreation, farming, and industry, as well as for fish and wildlife needs. The distribution of rainfall can cause floods and droughts, which affects streamflow, groundwater, water availability, water quality, recreation, and aquatic habitats. Ohio is bordered by the Ohio River and Lake Erie and has over 44,000 miles of streams and more than 60,000 lakes and ponds (State of Ohio, 1994). Nearly all the rural population obtain drinking water from groundwater sources.

The U.S. Geological Survey (USGS) works in cooperation with local, State, and other Federal agencies, as well as universities, to furnish decisionmakers, policymakers, USGS scientists, and the general public with reliable scientific information and tools to assist them in management, stewardship, and use of Ohio's natural resources. The diversity of scientific expertise among USGS personnel enables them to carry out large- and small-scale multidisciplinary studies. The USGS is unique among government organizations because it has neither regulatory nor developmental authority - its sole product is reliable, impartial, credible, relevant, and timely scientific information, equally accessible and available to everyone. The USGS Ohio Water Science Center provides reliable hydrologic and water-related ecological information to aid in the understanding of use and management of the Nation's water resources, in general, and Ohio's water resources, in particular. This fact sheet provides an overview of current (2012) or recently completed USGS studies and data activities pertaining to water resources in Ohio. More information regarding projects of the USGS Ohio Water Science Center is available at http://oh.water.usgs.gov/.

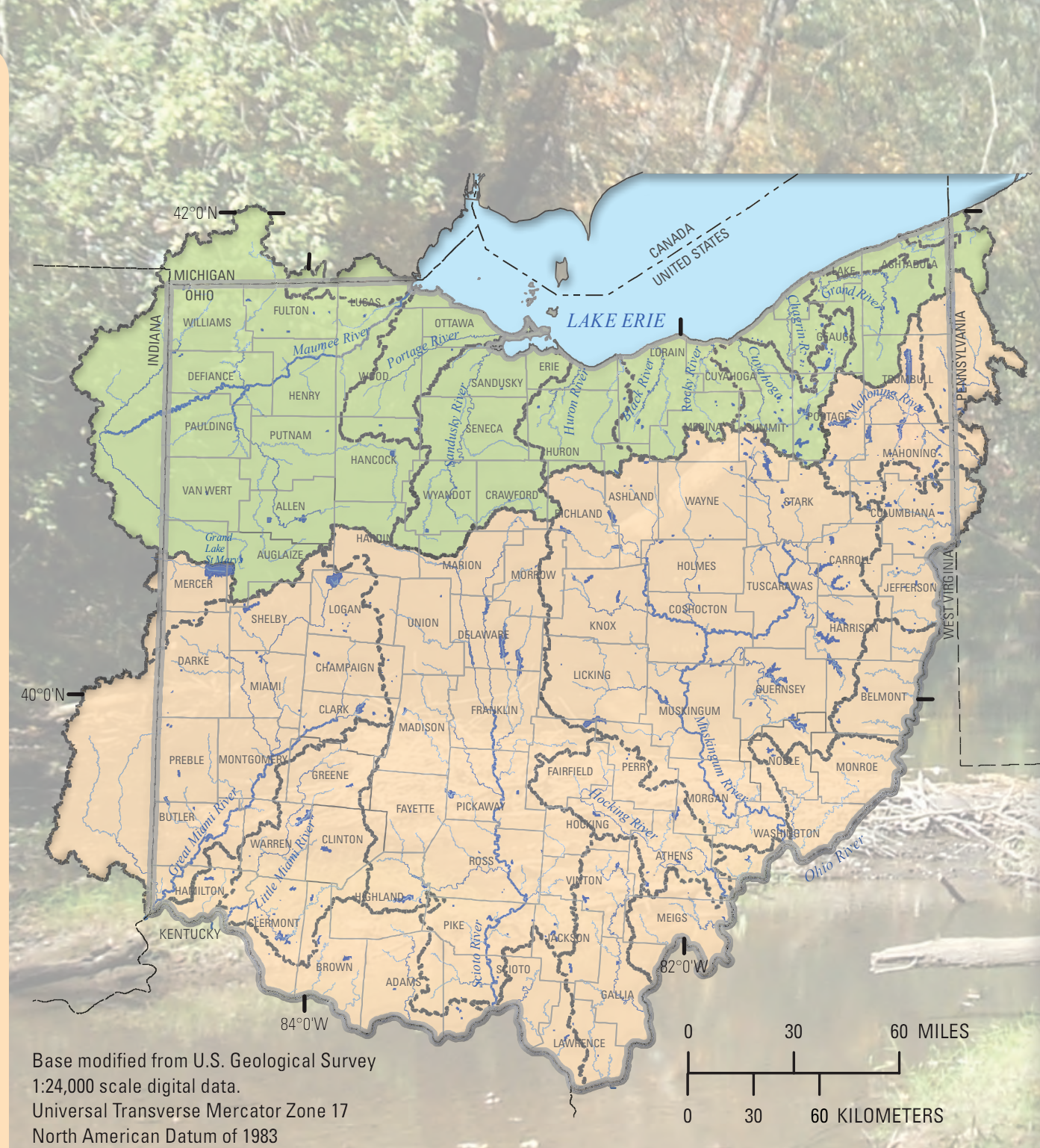

North American Datum of 1983

\section{EXPLANATION}

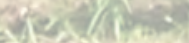

Major watershed

$1 . \because 3$ Watershed boundary
53 Ohio River Basin
53 Lake Erie Basin

Figure 1. Ohio basins and major watersheds. 

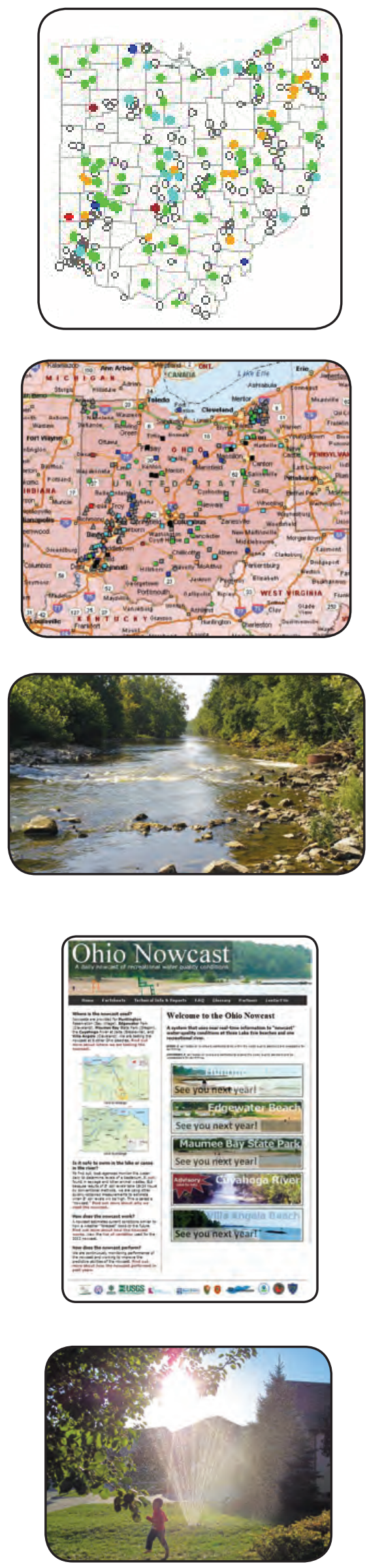

\section{Streamflow Data Available Online}

The USGS in Ohio - in cooperation with local, State, and Federal partners - operates about 230 streamgage stations, with about 160 gages recording streamflow. There are about 7,400 streamgages nationwide; many of these gages provide real-time data in 15-minute increments, which typically are transmitted to the Web every hour via satellite. These streamgages provide streamflow information for a wide variety of uses including flood prediction, water management and allocation, engineering design, research, operation of locks and dams, and recreational safety and enjoyment. In addition to these data, field-measurement data, streamflow statistics, and annual peak streamflows from each station are available on the Web through the National Water Information System (NWIS). http://waterdata.usgs.gov/oh/nwis/rt

For more information, contact James Mangus,jpmangus@usgs.gov.

\section{Groundwater Data Available Online}

State and local agencies in Ohio are responsible for collecting, researching, interpreting, and disseminating groundwater data to characterize the groundwater resources of the State. To address these needs, the Ohio Department of Natural Resources (ODNR) and the Miami Conservancy District (MCD) monitor groundwater levels at more than 140 wells throughout Ohio. Personnel from the USGS Ohio Water Science Center and ODNR compile and publish water levels on the Groundwater Watch and NWIS web sites. http://groundwaterwatch.usgs.gov/StateMaps/OH.html

For more information, contact Ralph Haefner, rhaefner@usgs.gov.

\section{Water-Quality Monitor Network in Ohio}

The USGS operates a network of near real-time water-quality monitoring stations that provides temperature, specific conductance, $\mathrm{pH}$, dissolved oxygen, and turbidity of surface water. These data are needed for decisionmaking regarding drinking water, water treatment, regulatory programs, recreation, healthy ecosystems, and public safety. Data are stored in the NWIS.

http://waterwatch.usgs.gov/wqwatch/

http://waterdata.usgs.gov/oh/nwis/current/?type $=$ quality\&group_key $=N O N E$

For more information, contact Kimberly Shaffer, kshaffer@usgs.gov.

\section{Nowcast-Water-Quality Conditions at Beaches and a Recreational River}

Local agencies monitor the water to measure the concentration of Escherichia coli (E. coli) - an indicator bacterium found in sewage and other animal wastes - to determine if it is safe to swim in a lake or canoe in a river. Conventional methods can take 18 to 24 hours to get results. To improve the timeliness and accuracy of recreational water-quality assessments, quick measurements, such as rainfall or water clarity, can be used to estimate the probability that $E$. coli exceeds safe levels. This "nowcast" system provides nearreal-time beach advisories to the public on the basis of predictive models. The USGS, in cooperation with many local and State agencies, is working to improve nowcast systems currently (2012) in operation and expand the use of operational predictive models and nowcast systems at more than 50 beaches throughout the Great Lakes and at inland lakes in Ohio.

http://www.ohionowcast.info/index.asp

For more information, contact Donna Francy,dsfrancy@usgs.gov.

\section{Ohio Water-Use Program}

Every five years since 1950, water-use data have been compiled and disseminated in Ohio as part of the USGS National Water-Use Information program. Current water-use categories include public supply, domestic, irrigation, livestock, aquaculture, industry, mining, and thermoelectric power. Water-use data are available by county and 8-digit Hydrologic Unit Codes.

http://oh.water.usgs.gov/water_use.html

For more information, contact Kimberly Shaffer, kshaffer@usgs.gov. 


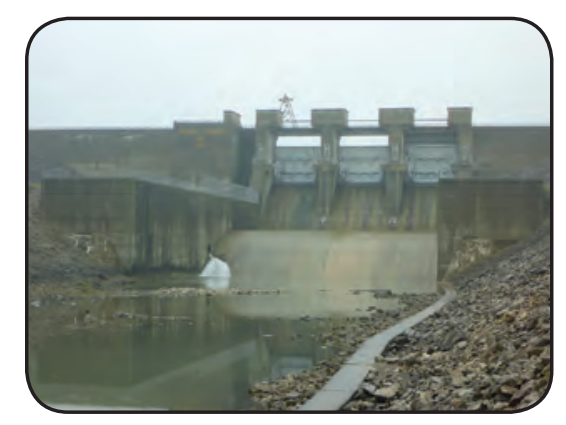

\section{Assessing Potential Climate-Change Effects in the Upper Scioto River Basin}

The central Ohio region is projected to grow by 450,000 people between 2005 and 2030 (Ohio Department of Development, 2003). The USGS is developing a watershed rainfall-runoff model to help water managers and planners assess whether existing and planned water-supply systems will be adequate to meet the region's future demand for water. This model will be used to estimate potential hydrologic effects of climate-change outcomes predicted by several climate-change models and will be instrumental for evaluating potential, future alternative water-management practices.

For more information, contact Chad Ostheimer, ostheime@usgs.gov.

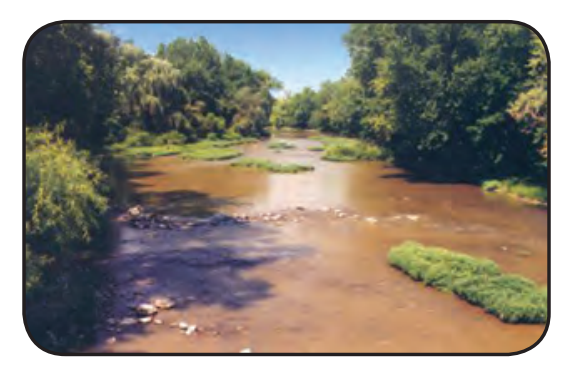

\section{Low-Flow Streamgage Network in Ohio}

Data on low-flow characteristics are used by water-resource managers for a variety of purposes, including water-supply planning, making decisions about wastewater-discharge and water-withdrawal permits, and evaluating in-stream flow requirements. The objective of this study is to collect low-flow data at locations throughout Ohio to expand the base of available information. The Ohio low-flow network consists of both continuous-record streamflow sites and sites where streamflow is only measured during low-flow periods. http://oh.water.usgs.gov/low-flow_network.html

For more information, contact Dave Straub, destraub@usgs.gov.

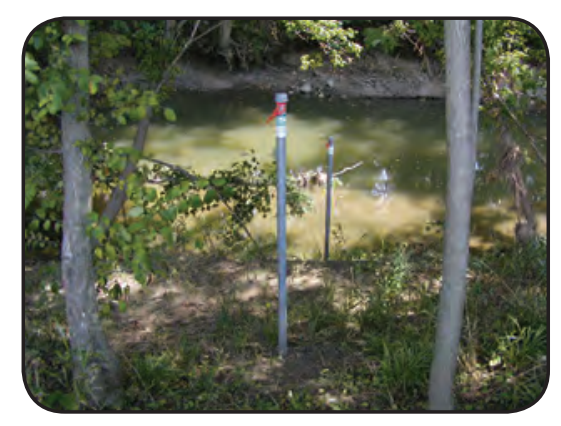

\section{Crest-Stage Streamgage Network in Ohio}

Historically, small streams with drainage areas less than 100 square miles have not been adequately represented in regional peak- (high) flow analysis. To help fill this data gap, crest-stage gages were installed during 2001 at 18 sites throughout Ohio to augment the peak-flow record for small-drainage-area streams. After enough peak-flow measurements have been collected at these sites, the statewide flood-frequency analysis will be updated to improve the estimation of peak flows.

http://oh.water.usgs.gov/crest-stage.html

For more information, contact Andrew Ebner, aebner@usgs.gov.

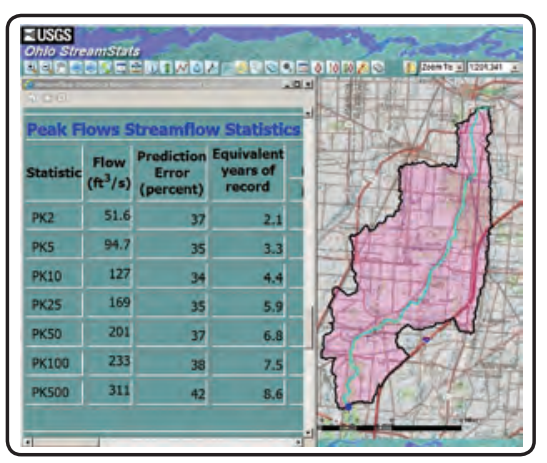

\section{StreamStats}

Ohio StreamStats is a Web-based Geographic Information System (GIS) application that allows users to easily obtain a variety of low flow and peak flow statistics; daily, monthly, and annual streamflow statistics; basin characteristics; and other information for ungaged stream sites in Ohio. Published statistics for gaged sites in the NWIS also are provided through the StreamStats map application. The StreamStats interface includes an assortment of analytical tools that are useful for water-resources planning and management.

http://water.usgs.gov/osw/streamstats/ohio.html

For more information, contact Greg Koltun,gfkoltun@usgs.gov.

\section{Flood-Studies and Flood-Warning Systems Program}

This program employs hydrologic and hydraulic analyses to determine water-surface elevations associated with specific flood magnitudes at several points along a stream channel. The water-surface elevation data are used together with land-surface elevation data to determine and map the corresponding spatial extent of flood inundation. In some cases, libraries of flood-inundation maps are prepared for stream channels near USGS gaging stations at which the National Weather Service (NWS) forecasts flood levels. In those cases, the NWS forecasts can be used in advance via map-based Web applications (for example, see http://wim.usgs.gov/FIMI) to determine areas that are likely to flood at the forecasted levels. These studies, and information developed, serve as a foundation for making science-based decisions to better manage flood risk and efforts to mitigate flood impacts.

http://water.usgs.gov/osw/flood_inundation/

(Photograph by Mary Terry, courtesy of Findlay Engineer's Office, Findlay, Ohio.) 


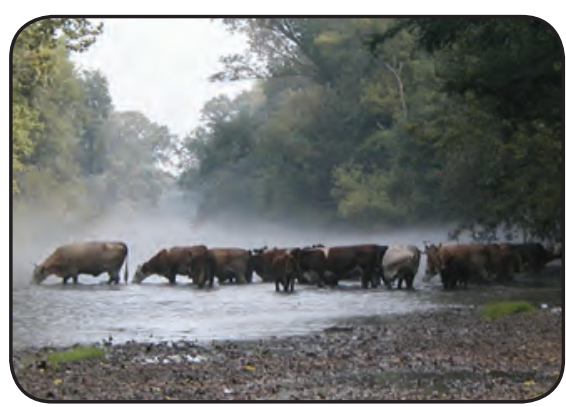

(Photograph by Brian Caskey, USGS.)
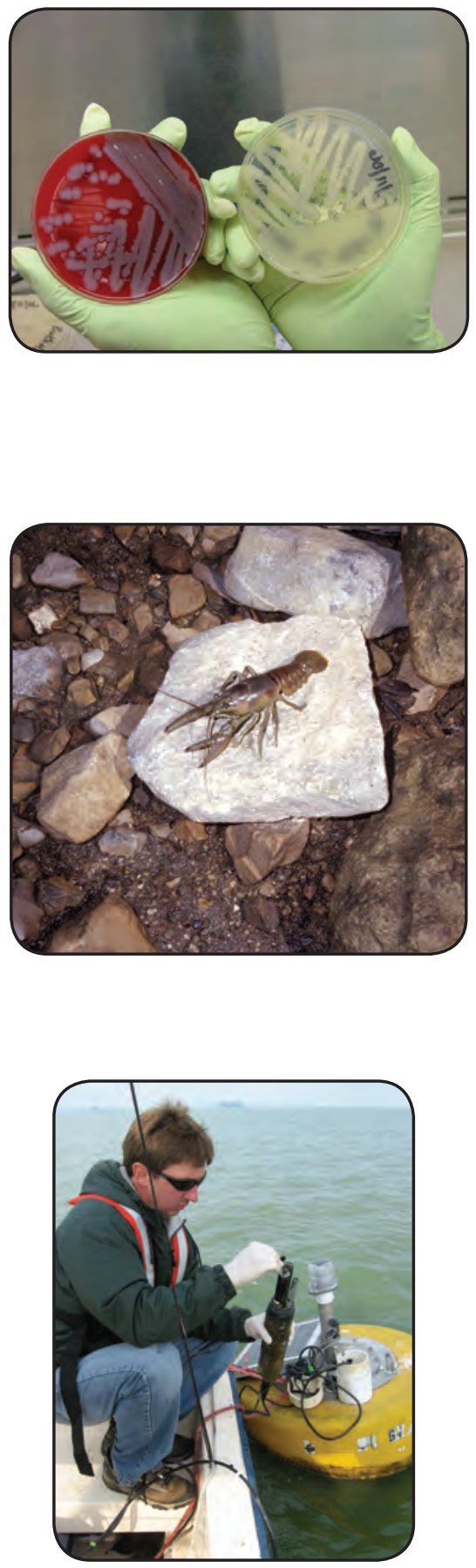

\section{Microbial Source Tracking}

The City of Columbus is in the process of updating its wastewater infrastructure and treatment-plant operations to reduce the occurrence of combined sewer overflows to waterways such as the Olentangy and Scioto Rivers. The USGS is working with the City to analyze river-water samples for microbial source tracking (MST) markers to help characterize the impact of various sources of fecal contamination. The USGS also is conducting MST analysis on a subset of river sites during wet and dry weather conditions.

http://oh.water.usgs.gov/micro_sourcetracking.htm

For more information, contact Chris Kephart, ckephart@usgs.gov.

\section{Testing Rapid Detection Methods for Drinking Water and Recreational Waters}

Rapid water-quality tests for microorganisms are needed to quickly ensure that water is safe for consumption or recreation. The USGS is developing and testing rapid methods for the detection of the viable (living) microorganisms that are potential biothreat agents in large-volume drinking-water samples-Bacillus anthracis (anthrax), Francisella tularensis (tularemia), and Yersinia pestis (plagues). Results from viability methods will be compared to culture and other method results. The USGS also has been working on optimizing and testing methods that will provide $E$. coli and enterococci results in 2 hours rather than the conventional 18-24 hours for recreational waters. The Ohio Water Microbiology Lab continues to optimize the methods, which are now being tested by numerous agencies.

http://oh.water.usgs.gov/micro_rapiddetection.htm

For more information, contact Rebecca Bushon, rnbushon@usgs.gov.

\section{Modeling Aquatic Species Distributions Based on Physical Habitat and Climate Change}

Gap analysis is a coarse-scale assessment of aquatic biodiversity and conservation, the results of which can be used to guide biological field studies and monitoring programs. Potential species distribution models were developed for 130 fish, 70 bivalve, and 17 native crayfish species based on a physical habitat-based classification of the perennial streams in Ohio.

A more recent study is integrating fish-habitat classifications and associated fishcommunity data with downscaled (regional) climate predictions under different change scenarios to identify vulnerabilities of river systems and to project likely changes to important fish species.

http://oh.water.usgs.gov/ohgap.htm

For more information, contact Alex Covert, sacovert@usgs.gov.

\section{Cyanobacteria and Toxins-Grand Lake St. Marys}

In recent years, measurements of microcystin (a toxin) associated with harmful algal blooms caused by cyanobacteria in Grand Lake St. Marys have exceeded recreationalwater guidelines, and the Ohio Environmental Protection Agency has issued water-quality advisories for the lake. The USGS, in cooperation with the Ohio Water Development Authority, City of Celina, and Grand Lake St. Marys State Park, is studying the distribution and timing of the occurrence of cyanobacteria and microcystin production and documenting the distributions of water-quality conditions and cyanobacteria, microcystin, and nutrient concentrations. Continuous water-quality conditions are being measured at two depths at one location, and water samples are being collected five times a year at six locations.

http://waterdata.usgs.gov/oh/nwis/ $u v /$ site_no $=403139084293900 \&$ PARAmeter_cd $=00010,00095,00300,00400$

For more information, contact Denise Dumouchelle,ddumouch@usgs.gov. 

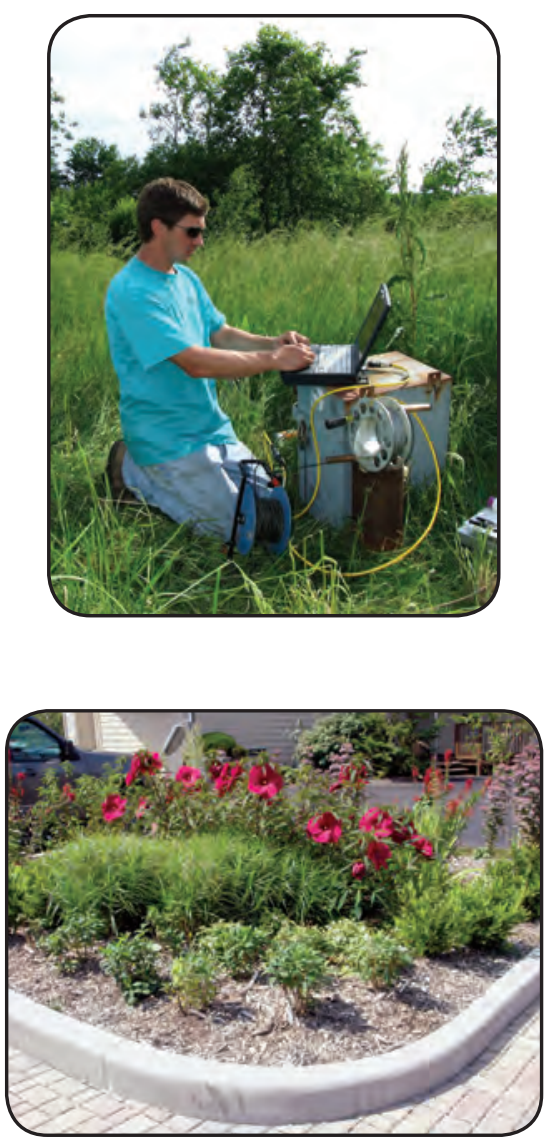

(Photograph by personnel of Cawrse and Associates, Inc., Chagrin Falls, Ohio.)
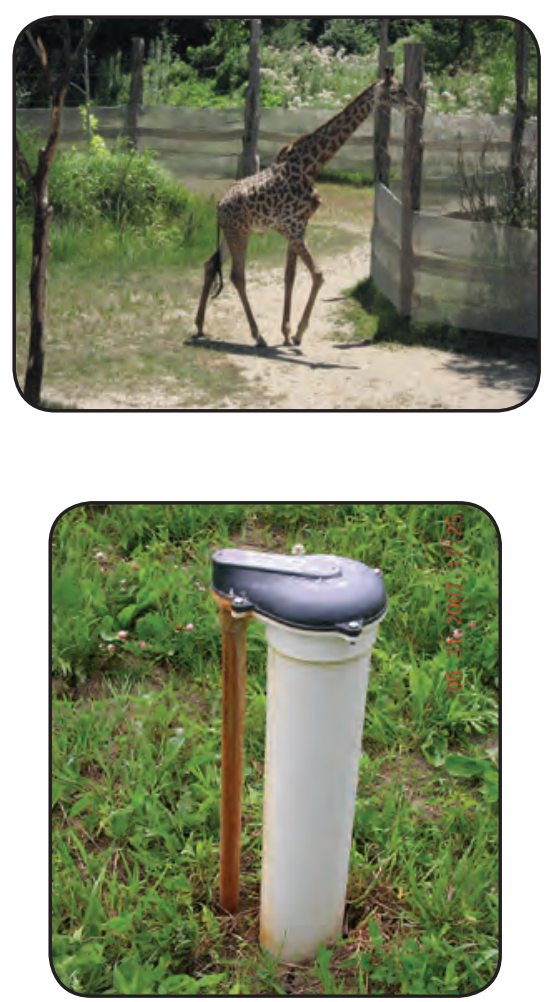

\section{Long-Term Water-Level Monitoring Network, Geauga County, Ohio}

Residents of Geauga County rely almost exclusively on groundwater as their source of drinking water. County planners are concerned that steady population growth, in combination with extensive groundwater use by county residents, will result in water being withdrawn faster than it is recharged. This study involves monitoring groundwater levels in 31 wells across the county that are in four widely used aquifers. Knowledge of the magnitude and locations of groundwater declines in the county are needed to assist in planning for continued growth and conservation of groundwater resources.

Another project, which monitors water levels from a network in the vicinity of South Russell Village, Geauga County, is used to evaluate whether variations in groundwater levels are caused by annual variations in precipitation or residential and commercial development.

http://groundwaterwatch.usgs.gov/countymaps/OH_055.html

For more information, contact Martha Jagucki,mjagucki@usgs.gov.

\section{Hydraulic Characteristics of Low-Impact Development Practices in Northeastern Ohio}

Low-impact development (LID) is an approach to managing storm water as near to its source as possible; this is accomplished by minimizing impervious surfaces and promoting more natural infiltration and evapotranspiration than is typically associated with developed areas. Two newly constructed LID sites in northeastern Ohio are being studied to document their hydraulic characteristics. One of the sites is a roadside best-management practice that replaced existing roadside ditches with a bioswale/rain garden, and the other site makes use of pervious pavers and a rain garden to receive runoff from the roof of a nearby commercial building.

http://pubs.usgs.gov/sir/2011/5165/

For more information, contact Robert Darner, radarner@usgs.gov.

\section{Hydrologic Influences of Storm-Water Best-Management Practices at the Cincinnati Zoo}

The Metropolitan Sewer District of Greater Cincinnati and the Cincinnati Zoo and Botanical Garden have undertaken a project to remove a parking lot and replace it with animal exhibits that incorporate best-management practices to reduce storm-water runoff. The USGS is collecting hydrologic data to help determine the influences of these practices on local groundwater. Monitoring currently (2012) includes measurement of water levels and quality in four wells and data collection at a weather station.

http://groundwaterwatch.usgs.gov/StateMaps/OH.html

For more information, contact Robert Darner, radarner@usgs.gov.

\section{Arsenic in Groundwater of Licking County}

Arsenic is odorless and tasteless and can enter drinking-water supplies from natural deposits in rock and soil. In some parts of Ohio, arsenic concentrations in groundwater can exceed the arsenic health standard of 10 parts per billion that the U.S. Environmental Protection Agency has set to protect consumers from the effects of long-term, chronic exposure to arsenic (U.S. Environmental Protection Agency, 2012). The USGS is investigating arsenic concentrations in water from domestic wells in Licking County as part of a broader effort to understand which parts of the groundwater system are most vulnerable to contamination from naturally occurring arsenic.

http://arsenicinohiogroundwater.info/

For more information, contact Mary Ann Thomas, mathomas@usgs.gov. 

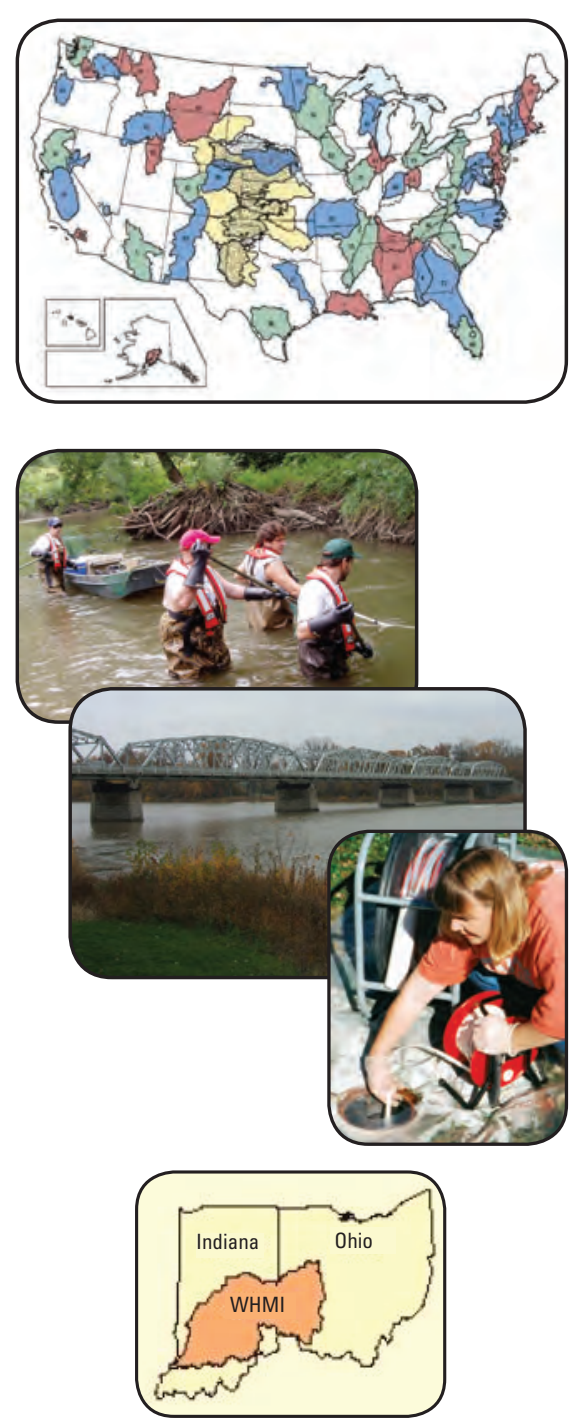

\section{References Cited}

Ohio Department of Development, 2003, Office of Policy Research and Strategic Planning, Population projections for Ohio and counties by age and sex, 2000 to 2030, accessed July 23, 2012, at $h t t p: / / w w w$.development.ohio.gov/ research/Reports_in_population_and housing-Population_Projections.htm.

State of Ohio, 1994, Ohio's water Ohio's future-1994 Final report: Governor's blue ribbon task force on water resources planning and development, 31 p. Accessed July 23, 2012, at www. dnr.state.oh.us/Portals/7/pubs/reports/ Ohiowaterfuture.pdf.

U.S. Environmental Protection Agency, 2012, Arsenic in drinking water, accessed June 15, 2012, at http://water. epa.gov/lawsregs/rulesregs/sdwal arsenic/index.cfm.

\section{National Water-Quality Assessment (NAWOA) Program}

The Lake Erie and Lake Saint Clair (LERI) Basins in Indiana, Michigan, New York, Ohio, and Pennsylvania and the White, Great, and Little Miami River (WHMI) Basins in Indiana and Ohio comprise 2 of more than 50 study units that are part of the USGS NAWQA program. The long-term goals of the NAWQA program are to describe waterquality status and trends in a large representative part of the Nation's surface-water and groundwater resources and to provide a sound, scientific understanding of the primary factors affecting the quality of these resources.

http://water.usgs.gov/nawqa/

For more information, contact Allison Kunze, aekunze@usgs.gov.

\section{Ecology, Streams, and Groundwater-Lake Erie and Lake Saint Clair Basins}

The LERI NAWQA ecology study includes the collection of habitat, fish, algae, and macroinvertebrate-community data from selected streams in the LERI study unit. Data have been collected since 1994 and are stored in an ecological database (BioData). https://aquatic.biodata.usgs.gov/

For more information, contact Stephanie Janosy, sjanosy@usgs.gov.

The LERI NAWQA surface-water status and trends study includes the collection of sediment and water-quality samples from the Maumee and Auglaize Rivers in Ohio. Since 1994, samples have been collected on these rivers for the NAWQA program.

For more information, contact Dennis Finnegan,dpfinneg@usgs.gov.

The LERI NAWQA groundwater study includes collecting groundwater-quality samples and measuring water levels in a glacial aquifer in three well networks made up of monitoring wells (in urban areas and areas relatively undisturbed by human activities) and domestic wells (in urban and agricultural areas).

For more information, contact Donna Runkle,dlrunkle@usgs.gov.

\section{Groundwater-White, Great, and Little Miami River Basins}

The groundwater study in the White, Great, and Little Miami River (WHMI) Basins in Indiana and Ohio includes the collection of groundwater-quality samples and measurement of groundwater levels in three well networks in the Glacial Aquifer System. For more information, contact Mary Ann Thomas, mathomas@usgs.gov.

\section{Other USGS Resources}

Climate and Land-Use Change

http://www.usgs.gov/climate_landuse/

Core Science Systems (Mapping)

http://www.usgs.gov/core_science_systems/

Ecosystems

http://www.usgs.gov/ecosystems/

compiled by Kimberly Shaffer, Stephanie Kula, Phil Bambach, and Donna Runkle

This fact sheet is available online at http://pubs.usgs.gov.

Figures, illustrations, text, and pictures were provided by U.S. Geological Survey personnel.

For additional information, contact

Director(dc_oh@usgs.gov)

U.S. Geological Survey

Ohio Water Science Center

6480 Doubletree Avenue

Columbus, OH 43229-1111

Phone: (614) 430-7700 Fax: (614) 430-7777

Publishing support provided by Bonnie J. Stich, Columbus Publishing Service Center

\author{
Energy and Minerals, and Environmental \\ Health \\ http://www.usgs.gov/resources_envirohealth/ \\ Natural Hazards \\ http://www.usgs.gov/natural_hazards/
}

